\title{
THE USE OF SOCIAL MEDIA WHATSAPP AMONG ENGLISH EDUCATION STUDENTS FOR SOLVING THESIS WRITING PROBLEMS
} Syarwan Ahmad $^{1 *}$, T. Zulfikar ${ }^{2}$, Fitri Hardiana ${ }^{3}$

${ }^{1 *}$ Lecturer, Program of English Language Education, Faculty of Teacher Training and Education, Universitas Islam Negeri Ar-Raniry Banda Aceh, Indonesia; ${ }^{2}$ Lecturer, Program of English Language Education, Faculty of Teacher Training and Education, Universitas Islam Negeri Ar-Raniry Banda Aceh, Indonesia; ${ }^{3}$ Student, Program of English Language Education, Faculty of Teacher Training and Education, Universitas Islam Negeri Ar-Raniry Banda Aceh, Indonesia.

Emails: ${ }^{1 *}$ syarwanahmad54@gmail.com, ${ }^{2}$ teuku.zulfikar@ar-raniry.ac.id, ${ }^{3}$ fitryhardiana97@gmail.com Article History: Received on $23^{\text {rd }}$ March 2020, Revised on $28^{\text {th }}$ April 2020, Published on $24^{\text {th }}$ May 2020

\begin{abstract}
Purpose of the study: This study aimed to analyze the use of social media, WhatsApp, among the UIN (Universitas Islam Negeri) Ar-Raniry's English Language Education Program undergraduate students for solving their thesis writing problems, focusing on the effects of the WhatsApp use and to inquire whether WhatsApp communication helps them solve their thesis writing problems.
\end{abstract}

Methodology: The design of this study is descriptive qualitative in nature. The researchers selected 30 English Language Education Program undergraduate students comprising 9 male and 21 female students who were writing theses as participants. This study used the semi-structured interview to collect detailed information needed for this research. The researchers used note-taking and recording device using Galaxy Note 8.

Main Findings: Findings revealed that the use of social media, WhatsApp, among the undergraduate students of the UIN Ar-Raniry' English Language Education Program, shows a positive impact on solving the problems they face regarding their thesis writing. The findings also indicated that the use of social media, WhatsApp, has put students at ease in solving their various problems regarding thesis writing constraints.

Application of the study: This study can be very useful for the students writing theses, and thesis supervisors. The findings of this research give insights and provide information and theories related to thesis writing issues. Studies on this issue lack in the field of education in general and thesis related problem sharing and supervisee-supervisor relationships in particular.

Novelty/Originality of the study: The findings justify how the use of WhatsApp brings about positive effects and partly solve students' thesis writing problems. The findings revealed that these research benefits readers enhance existing knowledge and contributes to the construction of new knowledge in the field of education. Therefore, researchers recommend further research on the effects and benefits or other aspects of social media usage.

Keywords: Social Media, Thesis, Writing, Problems, English.

\section{INTRODUCTION}

The purpose of this research was to investigate the use of social media, WhatsApp, among the UIN (Universitas Islam Negeri) Ar-Raniry's English Language Education undergraduate students for solving their thesis writing problems. In Indonesia for the undergraduate student level, it is called skripsi instead of a thesis. Skripsi is a term used to describe a scientific and research paper written by undergraduate students as a compulsory requirement to complete their studies at higher education (Poerwadarminta, 2002). Therefore, the term skripsi is later on used in this paper. Social media is "a group of Internet-based applications that build on the ideological and technological foundations of Web 2.0, and allow the creation and exchange of user-generated content." Social media are equipped with the capacity and the facility to discuss, create a forum for discussion, modify and share information in texts, images, videos and audios for the users (Singh \& Dwiyendi, 2013). Among the commonly used social media are WhatsApp, Facebook, YouTube, Instagram and Twitter (Kaplan \& Haenlein, 2010).

Most of UIN (Universitas Islam Negeri) Ar-Raniry's English Language Education Program undergraduate students have problems finishing their skripsi. The problems are derived from many sources such as lack of supervisors' time, difficulty to meet them or lack of knowledge sharing among those who are writing skripsi. They need effective device or media, which could help them communicate both with their supervisors and their peers. This investigation is to analyze the use of social media, WhatsApp, for solving skripsi writing problems.

The first research question is that "what are the perceived effects of social media, WhatsApp, used by students who are writing skripsi?" This research question aimed to find out the answers of the social media effects, WhatsApp, has on the easiness of the UIN (Universitas Islam Negeri) Ar-Raniry' English language Education Program undergraduate students who are at the writing skripsi stage. The research focused on the positive effects of the WhatsApp on writing theses. The reasons why they prefer to use WhatsApp to other devices and the advantages of WhatsApp application for solving students' skripsi writing problems and in what ways were inquired in this research. 
The second research question is that "can the use of social media, WhatsApp, communication help them solve their skripsi writing problems?" This research question was in search of the use of WhatsApp for skripsi concern communication. Whom the students communicate with to solve their skripsi writing problems was investigated. Whether they use WhatsApp to share their problems on skripsi writing issues was looked into, or if they use WhatsApp for other needs concerning skripsi writing.

Unfortunately, some of them have difficulty in writing skripsi. The complexity and difficulty of skripsi writing are due to some obstacles, academic and non-academic constraints. In this research, problems in skripsi include academic and non-academic issues. When they communicate with their peers who are at the skripsi writing stage as well, they may solve academic problems by learning from one another in terms of writing techniques or research issues. When it comes to communication with their supervisors, they may inquire into writing techniques or just making an appointment. The former may be academic issues and the latter could be a non-academic matter. The investigation focused on both issues of solving skripsi problems. Moreover, Adrian-Taylor, et al. (2007) stated that the root of conflict and difficulties between students and supervisors is lack of communication. Unfortunately, the literature lacks research on communication barriers and the device used to facilitate communication to support this determining final work completion. This is a real gap. The scarcity of research on communication problems of both students-students and supervisee-supervisor communication regarding skripsi writing is more likely to cause the failure or the delay of skripsi completion and prolong students' study time. Skripsi writing is the last phase of undergraduate students' study tenure. Some of them fail to finish their studies because of skripsi writing constraints. That is the reason why this piece of research is of significance. So far, there has been a very limited number of studies examining the issue of social media usage for helping students who are writing skripsi. Therefore, this inquiry tries to see the use of social media among UIN (Universitas Islam Negeri) Ar-Raniry's English Language Education Program undergraduate students for solving skripsi writing problems.

\section{LITERATURE REVIEW}

Writing skripsi is hard for students, especially those who write it in English and English is his or her foreign language. Paltridge and Starfield (2007) stated that for all students, writing skripsi is a challenge. For those who write it in English and whose first language is not English, the challenge is even greater. Based on her study Fajri (2016) concluded that, among other factors, students make mistakes in writing due to their lack of enthusiasm, motivation, and practice. According to Darmono and Hasan (2005) among the obstacles that students face in writing skripsi is that students' lack of knowledge in doing research, self-organization, time-management, lack of materials on the subject and bad rapport with the supervisor. Before the process of writing skripsi commences, 2 supervisors have been assigned to supervise and direct the students writing skripsi. Unfortunately, not all relationships with supervisors work out as planned. Commonly, the supervisee-supervisor relationships deteriorate (Blair, 2016). Being reluctant, anxious to meet the supervisor and difficulty communicating with the supervisor is another significant barrier. These phenomena have drawn the attention of researchers. A study done by Moskvicheva, et al.(2015) showed that supervisors' evaluations were often inaccurate and more related to external factors of the student research activities than their academic capacities. This research result concluded that it is necessary to have a focused training to improve the accuracy of expectations and evaluations and to create mutual understanding between supervisors and students. The social media application may partly solve this problem.

Nowadays, people tend to prefer reading in the form of online social media to print media (Othman et al., 2019). A study conducted by Obaidillah and Rahman (2018) on the impact of the internet and social media on students' reading habits indicated that students spend more hours on electronic media than on reading books. They enjoy more using and reading social media than reading books. Using social media, people communicate on almost all issues of life such as education, politics, faith, family and so on. A study conducted by Shamsuddin, et al.(2019) showed that social media application in a university is one of the most influential factors for future students to enroll in the university in Malaysia. WhatsApp, which was created by Brian Acton and Jan Koum in 2009, derived from a very famous English phrase used by youths worldwide: What's up? Meaning what is new? (Tiwari \& Sharma, n.d.). The use of WhatsApp is becoming more and more popular today compared to the use of traditional SMS (Gasaymeh \& Aldalalah, 2013; Gasaymeh \& Qablan, 2013; Balakrishnan \& Loo, 2012). A study conducted by Gasaymeh (2017) indicated that it is common among the students to use WhatsApp. They use WhatsApp for personal and social purposes daily. Bansal and Joshi (2014) investigated the experiences of college students on the use of WhatsApp. They found that the use of WhatsApp facilitated collaborative learning and increased social interaction among them and with the instructors. Students cooperate and collaborate in knowledge construction (Rovai, 2002). Rambe and Chipunza (2013) found that university students use this useful electronic tool to facilitate information sharing among them. Students share information using WhatsApp (Yeboah \& Ewur, 2014). Ngaleka and Uys (2013), based on their research finding, stated that students use WhatsApp as a communication tool outside the classroom for information on meetings and projects. A study conducted by Malecela $\underline{\text { (2016) }}$ on the perception of a university student in Malaysia. The result indicated that students perceived that WhatsApp was useful for students learning, educational communication and collaboration. They believed that WhatsApp was of use for communication with each other and the professor. They use WhatsApp to interact with people personally and socially and they enjoy using it (Gasaymeh, 2017). Ahad and Lim (2014) discovered that WhatsApp is popular among undergraduate students. They reported that undergraduate students use it because it is not expensive and user-friendly. 
Yeboah and Ewur (2014) asserted that WhatsApp makes communication easy and it makes information flow effectively. It is also easy for them to write and send messages in real-time. This finding is in line with what was found by Church and de Oliveira (2013) that the reasons for WhatsApp usage include reliability, immediacy, sense of connection and community, social influences, technical characteristics, and low cost. A research conducted by Arifin (2015) indicated that WhatsApp makes a difference in the behavior of students. Even though WhatsApp allegedly molds them to be introverted persons, it helps them communicate easily.

Due to the practicality of WhatsApp usage for communication purposes, more and more students use WhatsApp for communication means including for solving skripsi writing problems. The study conducted by Fathy and Fattah (2015) showed that WhatsApp technology could enhance students' active participation in the EFL classroom. The effectiveness of using WhatsApp messenger as one of the mobile learning tools is perceived to have helped students develop their writing skills. A study conducted by Sukrillah et al. (2017) on the use of WhatsApp in the Faculty of Islamic Economics of Juanda Bogor, Indonesia, indicated that the use of WhatsApp is very widespread. It serves as a medium for disseminating information and as a facility for discussion and education. In a higher education setting, when it comes to reaching out and engaging with students, the use of social media can be extremely useful. It improves the professorstudent relationship. A bulk of research shows that students-teachers use WhatsApp to communicate for academic purposes. The research also revealed that due to its user-friendly, WhatsApp is becoming the most effective social media tool for teachers to communicate with students (Kheryadi, 2017). Quality communication between teachers and students is of the essence. Students should be able to access teachers both in and outside the school building. It is very important to have indirect and technology-based communication at schools. Communication channels should be easy, attractive, and flexible, and using social media is essential. Junco et al. (2010) based on their investigation, stated that the use of social media, particularly WhatsApp has caused the communication between students and faculty to improve, provided an avenue for communication and promoted cooperation among students. Consequently, WhatsApp usage on campus has been proven useful.

\section{METHODOLOGY}

The objectives of this research are to investigate the effects of social media used by the students writing skripsi, and to see if social media communications help them solve skripsi writing problem. This study is an in-depth inquiry using qualitative research. As the nature of the research is exploring perceived impacts on the use of social media, such as the WhatsApp towards students' ability to solve their problems in writing the skripsi, it requires a methodology that requires in-depth exploration of the phenomenon through semi-structured in-depth interviews, and qualitative research is applicable for this purpose. The participants of the research were recruited using the Purposive Sampling technique since it requires researchers to identify those who meet the criteria of the inquiry. This technique of sampling is known as a non-probability form in which the researcher relies on his or her sound judgment in obtaining the representative sample (Sugiono, 2016). The participants of this research were the UIN (Universitas Islam Negeri) Ar-Raniry's English Language Education Program undergraduate students who were writing skripsi. The data were collected through a semistructured in-depth interview technique. The population of this study is those who were at the thesis writing stage, 150 students, out of 291 English Education Program undergraduate students entered UIN Ar-Raniry in the year of 2014. However, not all students writing skripsi were around when the investigation was carried out. Nor were all of the active students. Therefore, the researcher relies on his intelligent judgment in selecting the representative sample. There were 30 students considered appropriate as research participants, consisting of 9 male and 21 female students. The number is considered gender representative since there are about 30\% male and 70\% female students of the UIN (Universitas Islam Negeri) Ar-Raniry's English Language Education Program. The interview process was recorded by using the Samsung Galaxy Note 8. The interview took place in an interactional way referring to (Steward \& Cash, 2014). The researchers recorded the interview process and transcribed it into a transcript for data analysis (Creswell, 2008). The data were presented mostly in verbatim.

Table 1: List of English students from 2010 to 2019

\begin{tabular}{lcccc}
\hline No & Year of Entrance & Male Students & Female Students & Total \\
\hline 1. & 2010 & 34 & 55 & 89 \\
\hline 2. & 2011 & 20 & 57 & 77 \\
\hline 3. & 2012 & 43 & 76 & 283 \\
\hline 4. & 2013 & 76 & 207 & 291 \\
\hline 5. & 2014 & 69 & 222 & 225 \\
\hline 6. & 2015 & 62 & 136 & 246 \\
\hline 7. & 2016 & 92 & 154 & 236 \\
\hline 8. & 2017 & 67 & 169 & 271 \\
\hline 9. & 2018 & 69 & 202 & 180 \\
\hline 10. & 2019 & 38 & 142 & 2017 \\
\hline \multicolumn{7}{r}{} \\
\hline
\end{tabular}

Source: The administration office-UIN Ar-Raniry' English Language Education Program 
The table displays the students' entrance trends from 2010 to 2019. Even though the number of entering students drops in 2019 to 180 students, the entering number of the current academic years is above 200 students indicating trends of entrance stability. Apart from that of the Academic Year of 2011, the number of students entering the UIN (Universitas Islam Negeri) Ar-Raniry's English Language Education Program is steadily increasing in earlier years peaking in the academic year of 2014, 291 students, from which the participants of this research were involved. It is also interesting to see that the number of female students is much higher than that of male students for all academic years from 2010 to 2019.

\section{RESULTS}

The objectives of this research are to investigate the perceived effectiveness of social media used by the students writing skripsi, and to see if social media communication helps them solve problems in their skripsi writing. The data were collected mainly by in-depth semi-structured interviews. The interview was tailored to the research questions.

Our first inquiry in this study is the effect of social media used by EFL undergraduate students of UIN Ar-Raniry, who are writing skripsi?"

Here are excerpts of the responses related to our first research inquiry.

Student A: "I use W.A. to contact my supervisor, and it connects the user's phone number, so it is a simple App." Respondents use WhatsApp is due to its simplicity and practicality.

Student D: "Using the WhatsApp platform is very cheap. It is much cheaper than using a phone call." Respondents use WhatsApp because it is cheap. It is cheaper than making a phone call or SMS.

Student Z: "I prefer WhatsApp than other communication facilities because I don't have to reload phone credit." In addition to practicality, this statement also means that using WhatsApp is cheaper for them. As students, they can afford it.

Student E: "Using WhatsApp, you can also send pictures, video, or audio quickly. WhatsApp group is very useful for me. It is very quick and easy to use, very user-friendly. My supervisor also responds quickly by W.A." It is quick and user friendly.

Student T: "One of the benefits of WhatsApp is we can make W.A. group and discuss things online." Having WhatsApp forum students can discuss skripsi writing matters without gathering themselves physically.

Student U: "I like using WhatsApp because we can share our problems via W.A. forum with several classmates at the same time." Students like to use WhatsApp because the messaging allows real-time communication, synchronous.

Student S: "Yes, even we have created an online forum through W.A. for those of us who are writing skripsi." The respondents have created an online forum and built their community.

Student R: "I must to use WhatsApp because it is a trend for connection between supervisee and supervisor."

Student N: "If you ask me the effect, sir, I would say WhatsApp communication has become our culture." WhatsApp usage has become a common situation among students.

Student H: "It helps me arrange my schedule with my supervisor and obtain some information on research from my friends and literature as well. WhatsApp is very helpful for solving my skripsi problems." Here, respondents share information and arrange a schedule to meet their supervisors.

Student C: "We know in this modern era, social media, especially WhatsApp. Everyone uses WhatsApp to communicate with others. We can also use it for sending data, such as files. Actually, it is easy to use. Sometimes, we proofread one another's skripsi." Respondents use WhatsApp for a more academic issue, proofreading.

Student I: $\quad$ "My major problem is getting guidance. My supervisors are not easy to meet every time I need them. Like I said before, my supervisor is really busy. So, I cannot meet them directly. Then, WhatsApp is really helping me to discuss my problem." Here, WhatsApp is very useful to them for discussion with the supervisor.

Student J: "... My supervisors lack of time to give consultation. They may have their own jobs. They have their own business. They are busy. They have other jobs. So, I have to wait for the hours and hours to meet them for skripsi consultation. Fortunately, I have WhatsApp, and I communicate with them using WhatsApp. When I send them a message using WhatsApp, they respond very quickly." Respondents confirmed that WhatsApp is very helpful.

Student K: "WhatsApp make a shorter time for me to ask questions from my supervisor and friends."

Student N: "About the effects of W.A., I think as a shy student, I can communicate effectively and satisfactorily with my friends and my supervisors." 
Student O: "If you ask me about the effects of WhatsApp use, I think I feel I get closer to my supervisor because WhatsApp icon inside my tap. I mean, my gadget."

Student L: "WhatsApp group is useful for me. Because we can save our time... Sometimes, if we do not have WhatsApp, it is hard to communicate with friends of the same fate writing skripsi, and supervisors. By using WhatsApp, it is easy to chat with people every time we want, not a waste of time."

Student Y: "Almost all of my friends writing skripsi have WhatsApp. So, it is easy for us to communicate on skripsi writing issues." Since almost all of them have WhatsApp application, they can communicate easily on their final work, skripsi.

Student G: "My supervisor is a little bit busy. So, she informs us when she can guide us... I think WhatsApp is very effective."

Our second inquiry is concerned with the effectiveness of WhatsApp as a communication tool for solving the skripsi writing problem. This inquiry was then formulated into a research question, such as regarding the effectiveness in the use of social media, WhatsApp, communication to help solve EFL undergraduate problems in writing the skripsi.

Student B: "WhatsApp helps me to communicate with my supervisor. Sometimes, I can ask my friends questions and he or she answers quickly. First, I take pictures, and then I send it to my friend and my friend can correct my writing through the picture." Respondents academically help each other using WhatsApp.

Student E: "It is easy to communicate with friends and make an appointment with the supervisor. It is not a waste of time waiting for my supervisor to come in. Using WhatsApp, I ask for his time. He checks his schedule and decides the time we meet for skripsi consultation."

Student F: "Yes, of course, I can share my problem easily with my close friends on skripsi problems and I communicate them to my supervisor. However, I prefer a direct meeting with my supervisor after making an appointment using WhatsApp." In terms of supervisee-supervisor communication, some students use WhatsApp just for making an appointment.

Student L: "I think so, yes, I feel it. When I use WhatsApp, I can solve my problem, communication problem. I use social media, WhatsApp, I solve my problems by asking my friends on, for example, research questions or other parts of my skripsi, and making an appointment with my supervisors. It works very well." Concerning peer communication, most students use WhatsApp to help each other with writing techniques.

Student J: "WhatsApp help me communicate with my supervisors on skripsi problems and arrange my schedule with them, gain some information on research from friends, and seeking literature as well. One of my supervisors also provides feedbacks for skripsi revisions." To a certain extent, supervisors provide consultation and feedbacks for their students using WhatsApp.

Student Q: "WhatsApp is a new breakthrough, the innovation that makes the consultation process with supervisor fluent and less stressful..."

Student K: "Yes, when I want to discuss with my friends on skripsi problems, I use WhatsApp. Sometimes we are sharing our problems, grammar, sources, methodology, or other problems. Sometimes, my friend gives a good solution to my problem. I think WhatsApp is a very good communication medium for us as students." Here respondents share information using WhatsApp.

Student B: "We have WhatsApp and we make a group discussion on our skripsi examination among us who are at writing skripsi stage. When we have a problem, we type our problems on the forum. All members can get benefit from it. By discussion, we solve our problems." Respondents informed that they have online forums via WhatsApp and they help each other on skripsi munaqasyah, oral examination.

Student P: "WhatsApp is very very helpful for me because it not only facilitates online social meeting in the forum but also help me access up-to-date information from my peers."

Student F: "Yes, of course, I can share my problem easily with my close friends on skripsi problems and I communicate them to my supervisor."

Student M: "How can WhatsApp help me? I can communicate through W.A. Group with my friends. I can get information and share information on my skripsi work. I can upload a file, make a video call and discuss with my friends and supervisors. I am very satisfied communicating with supervisors and friends using WhatsApp, I think." 


\section{DISCUSSION}

\section{Easiness and Quickness of Communication}

Most of the students' responses reveal the positive effects of social media usage. Most of them consider that WhatsApp allows them to engage in efficient and effective communication with their supervisors and friends. The finding is in congruence with previous research findings (Chuttur, 2009; Ahad \& Lim,2014; Yeboah et al., 2014; Udenze, 2017). In fact, the benefit is not only for easy and quick communication with their supervisor and friend, but also for the correction of skripsi by their friends through discussion, problem sharing, or even proofreading. Problem or knowledge sharing is one of the main advantages of WhatsApp usage among students. Prior researchers commonly found this sort of finding (Ahad \& Lim, 2014; Tiwari \& Sharma, n.d.; Yeboah \& Ewur, 2014; Akintola, et al., 2016; Eyadat, 2016). The research findings also point out that social media usage allows students to write their skripsi more effectively.

The finding is consistence with Ahad and Lim's (2014) findings that WhatsApp is popular among undergraduate students because of its cheapness and user-friendly. This finding confirms previous inquiries as well (see Ahad \& Lim, 2014; Yeboah \& Ewur, 2014; Udenze, 2017). These are some of the main reasons that they prefer using WhatsApp for a means of communication in writing skripsi to other forms of social media. A common theme here suggests that easiness is one of the main advantages of WhatsApp usage for communication in this context. Based on the research findings and students' responses, it is safe to interpret that the use of social media (WhatsApp) can help them communicate with supervisors and friends easily and interactively. This finding is in consonance with what Ahad and Lim (2014), Bouhnik and Deshen (2014), and Montag, et al. (2015) have claimed. To a certain extent, students who are at the skripsi writing stage cooperate and collaborate with colleagues in completing their final academic work, skripsi. The finding is in line with what Zhitomirsky-Geffet \& Blau (2017) found that social media has opened up modern opportunities for interaction and collaboration among students and between students and teachers. This finding is relevant to the conclusion drawn by Rovai (2002) that using WhatsApp students cooperate and collaborate in the university setting. Some students acknowledged that using WhatsApp is affordable. This argument is relevant to the findings found by Church \& de Oliveira (2013) that the reasons for WhatsApp usage include reliability, immediacy, sense of connection and community, social influences, technical characteristics, and low cost. Using WhatsApp is even much cheaper than making a phone call and SMS. This result of the study is also consistent with the previous study that WhatsApp gradually replaces the function of SMS (Jisha \& Jebakumar, 2014).

\section{Making Appointment}

One of the main points of the responses indicates that WhatsApp is one of the most frequently used facilities for nonacademic justification, making an appointment, particularly with supervisors. This result is in agreement with what stated by BouhnikandDeshen (2014) as a finding of their qualitative study that teachers communicate with students using WhatsApp. As all lecturers are engaged in other jobs in addition to supervising students writing skripsi, students are told to make an appointment in advance before consulting him or her. It is a very practical and simple application for students writing skripsi to search for a supervisor's availability and his or her spare time. The students make an appointment in a very easy and quick way. The finding is in an alignment with what Malecela (2016) found based on the study of the perception of a university student in Malaysia that WhatsApp was useful for students' learning, educational communication and collaboration and the students believed that WhatsApp was very beneficial for communication with each other and the professor. These findings are also in line with the current theory stated by Baker and Oswald (2010) that social media use makes quality relationships. It is easy to communicate before having face-to-face discussions. Users feel more comfortable and more time for effective communication. The finding also indicates that the respondents of this study are satisfied with WhatsApp usage due to its capacity that allows them to share, upload files, and videos.

\section{Problem Sharing}

The other main benefit of social media use, as found in this study, is that it is a tool to share students' problems in completing their skripsi. Many students use social media, particularly WhatsApp, to share their challenges and difficulties in completing their skripsi with their friends and supervisors. Although it is also obvious that they do not always share all challenges and difficulties with their supervisors for various reasons, they keep communicating with their colleagues regarding the complexities of skripsi writing. This response is in alignment with what Lerman (2007) found that among the advantages of social media usage is that the user can share interests and get feedback from each other. It revealed that the participants of this study share and solve their skripsi problems using WhatsApp with friends and supervisors. The students communicate dan discuss matters pertaining to their skripsi writing in real-time as WhatsApp application allows them to discuss and share in the synchronous way in which students contribute and provide feedback at the same time. With WhatsApp facility, the students can also share one another in an asynchronous manner in which they can provide feedback at any time and at their own pace. Among important issues shared are about writing skripsi with acceptable grammatical structure, relevant sources, valid referencing styles, methodology, and other issues in line with the skripsi writing.

Apart from information closely related to our research inquiries, the researchers also uncovered an important fact that students at the skripsi writing stage suffer from psychological problems, such as having low motivation, unwillingness to engage in learning or laziness to complete their skripsi. They also have socio-cultural problems such as difficulties of 
meeting supervisors as well as linguistics problems, which is related to the level of students' English mastery. This important finding, while it is not very relevant to our inquiry, it becomes the basis for further research.

\section{CONCLUSION}

The use of social media WhatsApp is perceived to give positive effects for students writing skripsi. These positive impacts are due to the superiority, practicality, and quickness of WhatsApp. The students use WhatsApp commonly for communicating with supervisors and peers. They communicate with supervisors to identify their availability, which then allows them to set a meeting time or set the deadline for their work with the supervisors.

Most of the professors are nowadays busy with other commitments, which are not necessarily related to academic responsibilities. However, lecturers are also assigned to do multiple academic tasks, such as teaching, research and publication, community service, and other academic-related assignments, while supervising undergraduate students writing skripsi is only a part of their academic responsibilities. Some of them are also trusted to supervise graduate students writing theses. The situation is different from that of 20 years ago in which the students could see his or her supervisor more regularly without having set an appointment in advance. At this moment, most of professors or supervisors are happy to serve students for consultation if the latter makes an appointment ahead of time. Most supervisors are ready to set aside some of his or her valuable time if the student makes an appointment before meeting them. Therefore, without being proactive undergraduate students may fail to get priority from the supervisor for skripsi consultation. Thanks to the practicality of the WhatsApp facility, students can make an appointment and communicate with the supervisor for directions and advice regarding their skripsi accomplishment. On the student part, WhatsApp communication with their supervisors becomes fluent and less stressful. Above all, they also get closer to their supervisors due to WhatsApp communication.

In addition, students prefer to use WhatsApp because of its simplicity to send messages and to communicate interactively. The findings indicate that apart from communication with supervisors, students also use WhatsApp for discussion with their peers writing skripsi. They collaborate for a common goal finishing their skripsi. They correct each other's work; they inform one another; they share skripsi problems with their peers; they proofread each other's work. In this way, the supervisor does not need to spend a huge amount of time proofreading the students' skripsi. The finding is consistent with what Berndtsson et al. (2008) illustrated that if students' skripsi has been proofread means that the supervisor can spend less time commenting on the details. Quite a few students prefer face-to-face meetings with their supervisor. They use WhatsApp just for making an appointment. It is safe to infer from the description of the research result that almost all of the supervisees use WhatsApp to make an appointment with supervisors. In short, WhatsApp has positive effects on students writing skripsi and help solve their skripsi problems.

Except for this, as additional information from this research, students writing skripsi also have psychological problems (less motivated), socio-cultural barriers (lack of rapport between students and supervisor), and linguistic hindrances (English and grammar mastery).

The findings suggest that both students and supervisors use WhatsApp as a communication medium for skripsi supervision and consultation means. The usage should not be limited to this issue. WhatsApp medium could also be utilized for other academic purposes such as academic communication and discussion. Graduate students may have similar problems. Adrian-Taylor et al.(2007) stated that the root of conflict and difficulties between graduate students and supervisors is lack of communication. Therefore, the recommendation may also apply to supervisees of higher level like Master's Program students or even Ph.D. students.

\section{LIMITATION AND STUDY FORWARD}

No study covers all aspects of research problems. This research has limitations. It does not investigate the issues of WhatsApp usage exhaustively. This study was unable to discover the detailed information on the content of the communication fully. Further research on the other aspects of social media usage or on the scope and detail content of WhatsApp communication among students writing skripsi is recommended.

\section{ACKNOWLEDGMENT}

This research received no financial support. However, as a corresponding author, I am very grateful to Dr. T. Zulfikar, co-author, who has contributed so much for the accomplishment of this work proofreading and providing some feedbacks for improvement. I am also badly indebted to Ms. Hardiana for her hard work in data gathering. Finally, we are also very grateful to Dr. Yunisrina Qismullah Yusuf, who has directed us in many aspects of the enhancement of this work. Thank you very much indeed to everyone who has been involved in the completion of this article.

\section{AUTHORS CONTRIBUTION}

Dr. Syarwan Ahmad is the head of this research. Dr. T. Zulfikar has contributed a lot to the accomplishment of this scholarly work. He has proofread, provided some feedbacks, and carried out the similarity check of this work. Fitri Hardiana has also contributed significantly to this work by gathering most of the data, particularly field data, for this study. 


\section{REFERENCES}

1. Adrian-Taylor, S. R., Noels, K. A., \& Tischler, K. (2007). Conflict between international graduate students and faculty supervisors: Toward effective conflict prevention and management strategies. Journal of Studies in International Education, 11(1), 90-117. https://doi.org/10.1177/1028315306286313

2. Ahad, A. D. \& Lim, S.M.A. (2014). Convenience or nuisance? The 'WhatsApp' dilemma. Procedia-Social and Behavioural Sciences, 155, 189-196. https://doi.org/10.1016/j.sbspro.2014.10.278

3. Akintola, M., Bello, M. B., \& Daramola, D.S. (2016). Usage of WhatsApp as social media platform among undergraduate students. Nigerian Journal of Educational Technology, 1(1). 1-14.

4. Arifin, H. F. (2015). Pengaruh WhatsApp terhadap perilaku tertutup mahasiswa [The influence of WhatsApp on student's closed behavior]. (Bachelor's thesis). UIN Sunan Kalijaga, Yogjakarta.

5. Baker, L., \& Oswald, D. (2010). Shyness and online social networking services. Journal of Social and Personal Relationships, 27, 873-889. https://doi.org/10.1177/0265407510375261

6. Balakrishnan, V., \& Loo, H.S. (2012). Mobile phone and short message services appropriation, usage and behavioral issues among university students. Journal of Social Sciences, 8(3), 364-371). https://doi.org/10.3844/jssp.2012.364.371

7. Bansal, T., \& Joshi, D. (2014). A study of students' experiences of WhatsApp mobile learning. Global Journal of Human-Social Science, 14(4), 26-33.

8. Berndtsson, M., Hansson, J., Olsson, B., \& Lundell, B. (2008). Thesis project: A guide for students in computer science and information system ( $2^{\text {nd }}$ ed). Springer. https://doi.org/10.1007/978-1-84800-009-4

9. Blair, L. (2016). Writing a graduate thesis or dissertation. Springer. https://doi.org/10.1007/978-94-6300$\underline{426-8}$

10. Bouhnik, D., \& Deshen, M. (2014). WhatsApp goes to school: Mobile instant messaging between teachers and students. Journal of Information Technology Education Research, 13, 217-231. https://doi.org/10.28945/2051

11. Church, K., \& de Oliveira, R. (2013). What's up with WhatsApp? Comparing mobile instant messaging behavior with traditional SMS. Proceedings of Mobile HCI 2013 - Collaboration and Communication (pp. 352-361). Munich, Germany. https://doi.org/10.1145/2493190.2493225

12. Chuttur, M.Y. (2009). Overview of the Technology Acceptance Model: Origins, developments and future directions. Indiana University, USA. Sprouts:Working Papers on Information System, 9(37), 1-23.

13. Creswell, J. W. (2008). Educational research: Planning, conducting and evaluating quantitative and qualitative research ( $3^{\text {rd }}$ Ed.). Pearson Prentice Hall.

14. Darmono., \& Hasan, A. (2005). Menyelesaikan skripsi dalam satu semester [Complete a thesis in one semester]. Grasindos.

15. Eyadat, Y.A. (2016). Status of WhatsApp applications usage by the information technology and computer science students at Yarmouk University in Yordan. Proceedings of INTED2016 Conference (pp. 3585-3595). Valencia, Spain. https://doi.org/10.21125/inted.2016.1862

16. Fajri, N. (2016). Assessing unity, coherence and word usage in student writing. English Education Journal, 7(1), 102-116.

17. Fathy, S. \& Fattah, S. A. (2015).The effectiveness of using WhatsApp messenger as one of mobile learning technique to develop students' writing skills. Journal of Education and Practice, 6(32), 115-127.

18. Gasaymeh, A. M., \& Aldalalah, O.M. (2013). The impact of using SMS as learning support tool on students' learning. International Education Studies, 6(10), 112-123. https://doi.org/10.5539/ies.v6n10p112

19. Gasaymeh, A. M., \&Qablan, B.M. (2013). SMS as out-of-class, student-instructor interaction tool: A case study of Jordanian graduate students' perceptions usage. International Education Studies, 6(8), 147-160. https://doi.org/10.5539/ies.v6n8p147

20. Gasaymeh, A. M. (2017). University students' use of WhatsApp and their perceptions regarding its possible integration into their education. Global Journal of Computer Science and Technology: Interdisciplinary, $17(1), 1-9$.

21. Jisha, K., \&Jebakumar (2014). WhatsApp: A trend setter in mobile communication among Chennai Youth. IOSR Journal of Humanities and Social Science, 199(9), 1-6.

22. Junco, R., Heiberger, G., \&Loken, E. (2010). The effect of Twitter on college student engagement and grade. Journal of Computer Assisted Learning, 27(2), 119-132. https://doi.org/10.1111/j.1365-2729.2010.00387.x

23. Kaplan, A. M. \&Haenlein, M. (2010). User of the world, unite:The challenges and opportunities of social media. Business Horizons, 53(1), 59-68. https://doi.org/10.1016/j.bushor.2009.09.003

24. Kheryadi. (2017). The implementation of "Whatsapp" as a media of English language teaching. Loquen, 10(2), 1-13. https://doi.org/10.32678/loquen.v10i2.685

25. Lerman, K. (2007). Social information processing in news aggregation. IEEE Internet Computing, 11(6), 1628. https://doi.org/10.1109/MIC.2007.136

26. Malecela, I. O. (2016). Usage of Whatsapp among Postgraduate Students of Kulliyyah of Education, International Islamic University Malaysia. International Journal of Advanced Engineering Research and Science (IJAERS),3(10), 126-137. https://doi.org/10.22161/ijaers/310.21 
27. Montag, C., Błaszkiewicz, K., Sariyska, R., Lachmann, B., Andone, I., Trendafilov, B., Eibes, M., \& Markowetz, A. (2015). Smartphone usage in the $21^{\text {st }}$ century: Who is active on WhatsApp? BMC Research Notes, 8, 331-336. https://doi.org/10.1186/s13104-015-1280-Z

28. Moskvicheva, N., Bordovskaia, N., \&Darinskaya, L. (2015). The role of students' and supervisors' interaction in research projects: Expectations and evaluations. Procedia-Social and Behavioural Sciences, 117, 576-583. https://doi.org/10.1016/j.sbspro.2015.01.163

29. Ngaleka, A., \& Uys, W. (2013, June). M-learning with WhatsApp: A conversation analysis. In International Conference on e-Learning (p. 282). Academic Conferences International Limited.

30. Obaidillah, M. \& Rahman, M.A. (2018). The impact of internet and social media on the habit of reading books: A case study on Southern Region of Bangladesh. Studies in English Language and Education, 5(1), 25-39. https://doi.org/10.24815/siele.v5i1.8966

31. Othman, S. S., Nayan, L.M., Tiung, L.K., \& Hassan, F. (2019). Issues and challenges of future newspapers. Humanities and Social Sciences Reviews, 7(5), 364-373. https://doi.org/10.18510/hssr.2019.7541

32. Paltridge, B. \& Starfield, S. (2007). Thesis and dissertation writing in a second language. Routledge. https://doi.org/10.4324/9780203960813

33. Poerwadarminta, W.J.S. (2002). Kamusumum Bahasa Indonesia [Indonesian dictionary]. Balai Pustaka.

34. Rambe, P., \& Chipunza, C. (2013). Using mobile devices to leverage student access to collaborativelygenerated resources: A case of WhatsApp instant messaging at a South African University. International Conference on Advanced Information and Communication Technology for Education (ICAICTE 2013) (pp. 331-337). Atlantis Press. https://doi.org/10.2991/icaicte.2013.66

35. Rovai, A.P. (2002). Development of an instrument to measure classroom community. Internet and Higher Education, 17, 197-211. https://doi.org/10.1016/S1096-7516(02)00102-1

36. Shamsuddin, M. F, Ali, A.M., Wahid, R.B., \&Saidun, Z. (2019). Factors influence undergraduate students' decision making to enroll and social media application as an external factor. Humanities \& Social Sciences Reviews, 7(1),126-136. https://doi.org/10.18510/hssr.2019.7116

37. Singh, P. \& Dwivendi, Y.B. (2013). Social media and awareness in global society. International Journal of Humanities and Global \& Social Sciences, 1(1), 48-56.

38. Steward, C. J., \& Cash, W. (2014). Interviewing principles and practices. McGraw-Hill Education.

39. Sugiono. (2016). Metodologi penelitian kuantitatif, kualitatif, dan $R \& D$ [Quantitative, qualitative, research methodologies, and R \& D]. Alfabeta.

40. Sukrillah, A., Ratnamulyani, I. A., \& Kusumadinata, A. A. (2017). Pemanfaatan media social melalui Whatsapp group FEI sebagaisaranakomunikasi [Utilization of social media through Whatsapp group FEI as a communication facility]. Jurnal Komunikatio, 3(2), 95-103. https://doi.org/10.30997/jk.v3i2.919

41. Tiwari, R. P., \& Sharma, L. M. (n.d). Use of WhatsApp in knowledge sharing. Academia.edu. http://www.academia.edu/27143185/USE_OF_WHATSAPP_IN_KNOWLEDGE_SHARIN

42. Udenze, S. (2017). Is WhatsApp messaging subsuming conventional SMS? International Journal of Advance Research and Publications, 1(6), 105-109.

43. Yeboah, J., \& Ewur, G.D. (2014). The impact of WhatsApp messenger usage on students' performance in TertiaryInstitution in Ghana. Journal of Education and Practice,5(6), 157-164.

44. Yeboah, S.T., Horsu, E.N., \& Abdulai, A. (2014). Usage of WhatsApp and voice call (phone call): Preference of Polytechnic students in Ghana. Science Journal of Business and Management, 2(4), 103-108. https://doi.org/10.11648/j.sjbm.20140204.11

45. Zhitomirsky-Geffet, M., \& Blau, M. (2017). Cross-generational analysis of information seeking behaviour of smartphone users. Aslib Journal of Information Management, 69(6), 721-739. https://doi.org/10.1108/AJIM$\underline{04-2017-0083}$ 